\title{
The impact of heart failure and chronic obstructive pulmonary disease on mortality in patients presenting with breathlessness
}

\author{
Joseph J. Cuthbert ${ }^{1}$. Joshua W. Kearsley ${ }^{1}$. Syed Kazmi ${ }^{1}$. Anna Kallvikbakka-Bennett ${ }^{1}$. Joan Weston ${ }^{1}$. Julie Davis ${ }^{1}$. \\ Stella Rimmer ${ }^{1} \cdot$ Andrew L. Clark ${ }^{1}$
}

Received: 20 June 2018 / Accepted: 18 July 2018 / Published online: 8 August 2018

(C) The Author(s) 2018

\begin{abstract}
Background Differentiating heart failure from chronic obstructive pulmonary disease (COPD) in a patient presenting with breathlessness is difficult but may have implications for outcome. We investigated the prognostic impact of diagnoses of COPD and/or heart failure in consecutive patients presenting to a secondary care clinic with breathlessness.

Methods In patients with left ventricular systolic dysfunction (LVSD) by visual estimation, $\mathrm{N}$-terminal pro B-type natriuretic peptide (NTproBNP) levels and spirometry were evaluated $(N=4986)$. Heart failure was defined as either LVSD worse than mild (heart failure with reduced ejection fraction) or LVSD mild or better and raised NTproBNP levels ( $>400 \mathrm{ng} / \mathrm{L}$ ) (heart failure with normal ejection fraction). COPD was defined as forced expiratory volume in $1 \mathrm{~s}\left(\mathrm{FEV}_{1}\right)$ to forced vital capacity (FVC) ratio $<0.7$. The primary outcome was all-cause mortality.

Results 1764 (35\%) patients had heart failure alone, 585 (12\%) had COPD alone, 1751 (35\%) had heart failure and COPD, and $886(18 \%)$ had neither. Compared to patients with neither diagnosis, those with COPD alone [hazard ratio $(\mathrm{HR})=1.84$ 95\% confidence interval (CI) 1.40-2.43], heart failure alone [HR $=4.40$ (95\% CI 3.54-5.46)] or heart failure and COPD $[\mathrm{HR}=5.44$ (95\% CI 4.39-6.75) $]$ had a greater risk of death. COPD was not associated with increased risk of death in patients with heart failure on a multivariable analysis.

Conclusion While COPD is associated with increased risk of death compared to patients with neither heart failure nor COPD, it has a negligible impact on prognosis amongst patients with heart failure.
\end{abstract}

Keywords Heart failure $\cdot$ Chronic obstructive pulmonary disease $\cdot$ COPD $\cdot$ Mortality $\cdot$ Outcome $\cdot$ Prognosis

\section{Introduction}

Breathlessness is common. Separating heart failure from chronic obstructive airways disease (COPD), both or neither can be difficult due to similarity in symptomatology

These authors take responsibility for all aspects of the reliability and freedom from bias of the data presented and their discussed interpretation.

Electronic supplementary material The online version of this article (https://doi.org/10.1007/s00392-018-1342-z) contains supplementary material, which is available to authorized users.

Joseph J. Cuthbert

joe.cuthbert@nhs.net

1 Department of Academic Cardiology, Hull York Medical School, Hull and East Yorkshire Medical Research and Teaching Centre, Castle Hill Hospital, Cottingham, Kingston upon Hull HU16 5JQ, UK and shared risk factors, such as increasing age and smoking history. However, the distinction is important: there are numerous drug and device therapies that can prolong life in patients with heart failure and reduced ejection fraction (HeFREF) [1], but there is little evidence that commonly used treatments of COPD affect mortality [2]. In addition, patients with heart failure who are also diagnosed with COPD often receive suboptimal treatment, as they are less likely to be prescribed beta-blockers due to concerns about bronchoconstriction [3].

The ratio of forced expiratory volume in $1 \mathrm{~s}\left(\mathrm{FEV}_{1}\right)$ to forced vital capacity (FVC) below 0.7 indicates obstructive pulmonary disease [4], and many patients with heart failure also have obstructive spirometry [5, 6]. Estimates of the prevalence of COPD amongst patients with heart failure vary between 8 and $52 \%$ depending on the definition of COPD $[7,8]$, but the impact of a co-diagnosis of COPD and heart failure is not clear. 
The European Society of Cardiology heart failure guidelines state that the presence of COPD (regardless of the definition) is associated with worse prognosis in patients with HeFREF. However, numerous studies investigating the effect of COPD on outcome in patients with heart failure have been inconsistent [6,9-22]. Studies that have reported increased mortality amongst patients with heart failure and COPD compared with either diagnosis alone have either come from highly selected trial populations of patients with HeFREF [9, 15, 19], patients admitted with acute heart failure $[6,11,16]$, or have involved only short-term follow-up $[10,12,20]$. Up to half of patients with heart failure have a normal ejection fraction (HeFNEF) [23], but the prognostic significance of COPD amongst outpatients with HeFNEF has, so far, only been assessed in a small number of patients [22].

Reliable data on the long-term impact of a diagnosis of COPD on outcome in "real-world" outpatients with heart failure is scarce. We therefore assessed the impact of a diagnosis of COPD and/or heart failure on long-term mortality in a large cohort of consecutive ambulatory patients with breathlessness referred to a secondary care clinic with suspected heart failure.

\section{Methods}

\section{Setting, study design and patients}

Between September 2000 and October 2016, all clinical, demographic, biochemical and echocardiographic data on consecutive patients referred from primary or secondary care to a community heart failure clinic serving a local population of about 500,000 people were recorded on a secure database (Hull LifeLab). Patients were followed-up until 1st November 2016. All subjects gave their written informed consent for their data to be used. The study conforms to the principles outlined in the Declaration of Helsinki and was approved by relevant ethical bodies.

\section{Definitions and outcome}

Heart failure was defined as the presence of signs and symptoms of the disease and either left ventricular dysfunction (LVSD) worse than mild-HeFREF; or LVSD mild or better and $\mathrm{N}$-terminal peptide of pro B-type natriuretic peptide (NTproBNP) level $>400 \mathrm{ng} / \mathrm{L}-\mathrm{HeFNEF}$ [24]. Spirometry was performed routinely on all patients at baseline by trained nursing staff. COPD was defined as $\mathrm{FEV}_{1}: \mathrm{FVC}<0.7$ as suggested by the GOLD criteria [4]. The primary outcome was all-cause mortality.

\section{Statistical analysis}

Categorical data are presented as number and percentages, normally distributed continuous data are presented as mean \pm standard deviation (SD) and non-normally distributed variables are presented as median and interquartile range (IQR).

The relationship between $\mathrm{FEV}_{1}: \mathrm{FVC}$ and other variables was assessed by Pearson's correlation coefficient and linear regression. Variables associated with COPD as a categorical variable $\left(\mathrm{FEV}_{1}: \mathrm{FVC}<0.7\right)$ were assessed using logistic regression. Only variables with $P<0.1$ (an arbitrary threshold) in univariable analysis were included in multivariable models. Log-transformed NTproBNP was used.

Patients with were divided into groups: heart failure alone; COPD alone; heart failure and COPD; and neither diagnosis. Patients with heart failure were sub-divided into those with HeFREF or HeFNEF. Chi-squared tests were used to compare categorical variables and one-way analysis of variance (ANOVA) to compare continuous variables across the groups. Assumptions of ANOVA (normality of residuals and equal variance) were checked. Kruskal-Wallis test was used to compare non-normally distributed continuous variables across quartiles and groups.

Associations between variables and outcome were assessed with Cox regression. Proportionality of hazards was checked by residual plotting. Univariable analysis was conducted using all variables in the dataset: variables with $P>0.1$ in univariable analysis or with more than $10 \%$ missing values (an arbitrary threshold) were not included in the multivariable analyses. Kaplan-Meier curves were used to demonstrate outcome by group.

All statistical analyses were carried out using the SPSS 24 software package with the two-tailed level of statistical significance set at $P<0.05$.

\section{Results}

Of 4986 patients, 1764 (35\%) had heart failure alone, 585 (12\%) had COPD alone, 1751 (35\%) had both heart failure and COPD, and 886 (18\%) had neither condition (Table 1). Of the 3515 total patients with heart failure, 2329 had HeFREF and 1186 had HeFNEF. The prevalence of COPD reported in the medical record (10\% for HeFREF; $10 \%$ HeFNEF) was far lower than the prevalence of COPD by spirometry (49\% for HeFREF; $51 \%$ for HeFNEF), but was 
Table 1 Patient characteristics: all patients

\begin{tabular}{|c|c|c|c|c|c|c|c|}
\hline \multirow[t]{2}{*}{ Variable } & \multirow[t]{2}{*}{ Missing } & \multirow{2}{*}{$\begin{array}{l}\text { All patients } \\
N=4986\end{array}$} & \multirow{2}{*}{$\begin{array}{l}\text { Heart failure } \\
N=1764\end{array}$} & \multirow{2}{*}{$\begin{array}{l}\text { COPD } \\
N=586\end{array}$} & \multirow{2}{*}{$\begin{array}{l}\text { Heart failure and COPD } \\
N=1750\end{array}$} & \multirow{2}{*}{$\begin{array}{l}\text { Neither heart } \\
\text { failure nor } \\
\text { COPD } \\
N=886\end{array}$} & \multirow[t]{2}{*}{$P$} \\
\hline & & & & & & & \\
\hline \multicolumn{8}{|l|}{ Demographics } \\
\hline Age (years) & 0 & $71( \pm 11)$ & $71( \pm 12)$ & $71( \pm 10)$ & $75( \pm 10)$ & $66( \pm 12)$ & $<0.001$ \\
\hline Sex (male) $-N(\%)$ & 0 & $3068(62)$ & $1197(68)$ & $273(47)$ & $1139(65)$ & $459(52)$ & $<0.001$ \\
\hline BMI $\left(\mathrm{kg} / \mathrm{m}^{2}\right)$ & 17 & $28.7( \pm 6.0)$ & $29.1( \pm 6.1)$ & $29.2( \pm 5.6)$ & $27.4( \pm 5.7)$ & $30.1( \pm 6.2)$ & $<0.001$ \\
\hline $\operatorname{SR}[N(\%)]$ & 80 & $3562(71)$ & $1087(63)$ & $559(96)$ & $1060(62)$ & $3562(73)$ & $<0.001$ \\
\hline Diabetes $[N(\%)]$ & 308 & $970(20)$ & $407(24)$ & $80(15)$ & $334(21)$ & 149 (18) & $<0.001$ \\
\hline $\operatorname{IHD}[N(\%)]$ & 31 & $2259(45)$ & $912(52)$ & $151(26)$ & $935(54)$ & $261(30)$ & $<0.001$ \\
\hline $\begin{array}{l}\text { Documented COPD } \\
\text { in medical records } \\
{[N(\%)]}\end{array}$ & 31 & $478(10)$ & $118(7)$ & $86(15)$ & $223(13)$ & $51(6)$ & $<0.001$ \\
\hline Never smoked $[N(\%)]$ & 319 & $1421(30)$ & $536(33)$ & $158(29)$ & $383(24)$ & $344(41)$ & $<0.001$ \\
\hline \multicolumn{8}{|l|}{ Symptoms } \\
\hline $\begin{array}{l}\text { NYHA Class III/IV } \\
{[\mathrm{N}(\%)]}\end{array}$ & 245 & $1344(28)$ & $537(31)$ & $90(17)$ & $617(36)$ & $100(14)$ & $<0.001$ \\
\hline \multicolumn{8}{|l|}{ Blood results } \\
\hline NTproBNP [ng/L] & 461 & $723(179-2045)$ & $1319(656-2821)$ & $140(73-228)$ & $1590(742-3309)$ & $113(57-203)$ & - \\
\hline Haemoglobin $[\mathrm{g} / \mathrm{dL}]$ & 395 & $13.5(12.3-14.5)$ & $13.4(12.1-14.5)$ & $13.8(12.9-14.7)$ & $13.2(12.0-14.3)$ & $13.9(13.0-14.9)$ & $<0.001$ \\
\hline $\begin{array}{l}\text { eGFR }[\mathrm{mL} / \\
\left.\mathrm{min} / 1.73 \mathrm{~m}^{2}\right]\end{array}$ & 346 & $62(48-77)$ & $59(44-74)$ & $71(58-83)$ & $56(42-70)$ & $74(62-87)$ & $<0.001$ \\
\hline Albumin $[\mathrm{g} / \mathrm{L}]$ & 341 & $38(36-40)$ & $38(35-40)$ & $39(37-40)$ & $37(35-39)$ & $39(37-41)$ & $<0.001$ \\
\hline \multicolumn{8}{|l|}{ Spirometry } \\
\hline $\mathrm{FEV}_{1}[\mathrm{~L}]$ & 0 & $1.76( \pm 0.81)$ & $1.96( \pm 0.76)$ & $1.51( \pm 0.72)$ & $1.38( \pm 0.60)$ & $2.30( \pm 0.87)$ & $<0.001$ \\
\hline FVC [L] & 0 & $2.58( \pm 1.00)$ & $2.46( \pm 0.95)$ & $2.78( \pm 1.07)$ & $2.49( \pm 0.95)$ & $2.87( \pm 1.09)$ & $<0.001$ \\
\hline $\mathrm{FEV}_{1}: \mathrm{FVC}$ & 0 & $0.69( \pm 0.16)$ & $0.80(0.09)$ & $0.54( \pm 0.13)$ & $0.56( \pm 0.12)$ & $0.80( \pm 0.09)$ & - \\
\hline \multicolumn{8}{|l|}{ Medications } \\
\hline Loop diuretic $[N(\%)]$ & 107 & $2932(60)$ & $1240(71)$ & $191(34)$ & $1265(73)$ & $236(28)$ & $<0.001$ \\
\hline $\operatorname{MRA}[N(\%)]$ & 107 & $886(18)$ & $443(25)$ & $25(5)$ & $382(22)$ & $36(4)$ & $<0.001$ \\
\hline $\mathrm{ACEI}$ or ARB $[N(\%)]$ & 107 & $3142(63)$ & $1266(73)$ & $248(44)$ & $1250(72)$ & $378(45)$ & $<0.001$ \\
\hline$\beta \mathrm{B}[N(\%)]$ & 107 & $2503(50)$ & $1090(63)$ & $170(30)$ & $948(55)$ & $295(35)$ & $<0.001$ \\
\hline \multicolumn{8}{|l|}{ Echocardiography } \\
\hline Severe LVSD $[N(\%)]$ & 0 & $411(8)$ & 207 (12) & $0(0)$ & 204 (12) & $0(0)$ & - \\
\hline $\mathrm{HeFNEF}[N(\%)]$ & 0 & $1186(24)$ & $583(33)$ & $0(0)$ & $603(34)$ & $0(0)$ & - \\
\hline
\end{tabular}

Continuous data are presented as mean ( \pm standard deviation) or median (interquartile range), categorical data are presented as $N$ (percentage)

$N$ number; $C O P D$ chronic obstructive pulmonary disease; $B M I$ body mass index; $S R$ sinus rhythm; $I H D$ ischaemic heart disease; NYHA New York Heart Association; NTproBNP N-terminal B-type natriuretic peptide; $e G F R$ estimated glomerular filtration rate; $F E V_{1}$ forced expiratory volume in one second; $F V C$ forced vital capacity; $M R A$ mineralocorticoid receptor antagonist; $A C E I$ angiotensin converting enzyme inhibitor; $A R B$ angiotensin receptor blocker; $\beta B$ beta-blocker; $L V S D$ left ventricular systolic dysfunction; HeFNEF heart failure with normal ejection fraction

similar between the groups $(P=0.20)$ (Table 2) (Supplementary Fig. 1).

\section{Patient characteristics}

Patients with COPD alone had similar NTproBNP levels and symptom severity but were older than patients with neither heart failure nor COPD. Atrial fibrillation was far less common in patients with COPD alone than in those with heart failure alone, heart failure and COPD or neither condition.

Patients with heart failure alone were similar in their age and smoking history but had more severe symptoms than patients with COPD alone. Patients with heart failure and COPD had similar symptom severity and rate of loop diuretic prescription but were older, had higher NTproBNP 
Table 2 Patient characteristics: all patients with heart failure $(N=3515)$

\begin{tabular}{|c|c|c|c|c|c|c|c|}
\hline \multirow[t]{2}{*}{ Variable } & \multirow[t]{2}{*}{ Missing } & $\begin{array}{l}\text { All patients with } \\
\text { heart failure }\end{array}$ & HeFREF & HeFNEF & $\begin{array}{l}\text { HeFREF and } \\
\text { COPD }\end{array}$ & $\begin{array}{l}\text { HeFNEF and } \\
\text { COPD }\end{array}$ & \multirow[t]{2}{*}{$P$} \\
\hline & & $N=3515$ & $N=1181$ & $N=583$ & $N=1148$ & $N=603$ & \\
\hline \multicolumn{8}{|l|}{ Demographics } \\
\hline Age (years) & 0 & $73( \pm 11)$ & $69( \pm 12)$ & $75( \pm 10)$ & $73( \pm 10)$ & $77( \pm 8)$ & $<0.001$ \\
\hline Sex (male) $-N(\%)$ & 0 & $2336(67)$ & $871(74)$ & $326(56)$ & $851(74)$ & $288(48)$ & $<0.001$ \\
\hline $\mathrm{BMI}\left[\mathrm{kg} / \mathrm{m}^{2}\right]$ & 13 & $28.3( \pm 5.9)$ & $28.7( \pm 5.7)$ & $29.9( \pm 6.8)$ & $26.9( \pm 5.2)$ & $28.4( \pm 6.3)$ & $<0.001$ \\
\hline $\mathrm{SR}[N(\%)]$ & 65 & $2148(62)$ & 809 (70) & $278(48)$ & $754(67)$ & $307(52)$ & $<0.001$ \\
\hline Diabetes $[N(\%)]$ & 206 & $742(22)$ & $278(25)$ & $129(24)$ & $216(20)$ & $119(21)$ & 0.07 \\
\hline $\operatorname{IHD}[N(\%)]$ & 12 & $1848(53)$ & $713(61)$ & $199(35)$ & $735(64)$ & $201(33)$ & $<0.001$ \\
\hline $\begin{array}{l}\text { Documented } \\
\text { COPD in medi- } \\
\text { cal records }[N \\
(\%)]\end{array}$ & 12 & $341(10)$ & $74(6)$ & $44(8)$ & $149(13)$ & $74(12)$ & $<0.001$ \\
\hline $\begin{array}{l}\text { Never smoked }[N \\
(\%)]\end{array}$ & 237 & $919(28)$ & $332(30)$ & $204(37)$ & $215(20)$ & $168(30)$ & $<0.001$ \\
\hline \multicolumn{8}{|l|}{ Symptoms } \\
\hline $\begin{array}{l}\text { NYHA Class III/ } \\
\text { IV }[N(\%)]\end{array}$ & 59 & $1154(33)$ & $373(33)$ & $164(28)$ & $424(38)$ & $193(33)$ & $<0.001$ \\
\hline \multicolumn{8}{|l|}{ Blood results } \\
\hline NTproBNP (ng/L) & 461 & $1421(695-3109)$ & $1444(536-3486)$ & $1192(737-2241)$ & $1825(708-4013)$ & $1328(773-2542)$ & $<0.001$ \\
\hline $\begin{array}{l}\text { Haemoglobin (g/ } \\
\text { dL) }\end{array}$ & 294 & $13.3(12.1-14.4)$ & $13.6(12.3-14.7)$ & $13.1(11.8-14.2)$ & $13.3(12.2-14.4)$ & $12.9(11.7-14.2)$ & $<0.001$ \\
\hline $\begin{array}{l}\mathrm{eGFR}(\mathrm{mL} / \\
\left.\min / 1.73 \mathrm{~m}^{2}\right)\end{array}$ & 287 & $58(43-72)$ & $59(46-74)$ & $59(43-74)$ & $56(43-70)$ & $56(41-69)$ & $<0.001$ \\
\hline Albumin (g/L) & 281 & $37(35-40)$ & $38(35-40)$ & $37(35-39)$ & $37(35-40)$ & $37(34-39)$ & $<0.001$ \\
\hline \multicolumn{8}{|l|}{ Spirometry } \\
\hline $\mathrm{FEV}_{1}: \mathrm{FVC}$ & 0 & $0.68( \pm 0.16)$ & $0.80( \pm 0.10)$ & $0.80( \pm 0.08)$ & $0.56( \pm 0.12)$ & $0.56( \pm 0.11)$ & $<0.001$ \\
\hline \multicolumn{8}{|l|}{ Medications } \\
\hline $\begin{array}{l}\text { Loop diuretic }[N \\
\quad(\%)]\end{array}$ & 37 & $2505(72)$ & $872(75)$ & $368(64)$ & $857(75)$ & $408(68)$ & $<0.001$ \\
\hline $\operatorname{MRA}[N(\%)]$ & 37 & $825(24)$ & $371(32)$ & $72(13)$ & $309(27)$ & $73(27)$ & $<0.001$ \\
\hline $\begin{array}{l}\text { ACEI or ARB }[N \\
(\%)]\end{array}$ & 37 & $2517(72)$ & $906(78)$ & $360(62)$ & $890(78)$ & $361(61)$ & $<0.001$ \\
\hline$\beta \mathrm{B}[N(\%)]$ & 37 & 2039 (59) & $744(64)$ & $346(60)$ & $639(56)$ & $310(52)$ & $<0.001$ \\
\hline \multicolumn{8}{|l|}{ Echocardiography } \\
\hline $\begin{array}{l}\text { Severe LVSD [N } \\
(\%)]\end{array}$ & 0 & $916(26)$ & 457 (39) & $0(0)$ & $459(40)$ & $0(0)$ & - \\
\hline $\begin{array}{l}\text { LVEF by } \\
\text { Simpsons (\%) }\end{array}$ & 1511 & $38.2( \pm 12.6)$ & $32.8( \pm 8.0)$ & $54.6( \pm 6.7)$ & $32.4( \pm 8.2)$ & $55.8( \pm 7.64)$ & - \\
\hline
\end{tabular}

Continuous data are presented as mean ( \pm standard deviation) or median (interquartile range), categorical data are presented as $N$ (percentage)

$N$ number; HeFREF heart failure with a reduced ejection fraction; HeFNEF heart failure with normal ejection fraction; $C O P D$ chronic obstructive pulmonary disease; BMI body mass index; SR sinus rhythm; IHD ischaemic heart disease; NYHA New York Heart Association; NTproBNP $\mathrm{N}$-terminal B-type natriuretic peptide; $e G F R$ estimated glomerular filtration rate; $F E V_{l}: F V C$ ratio of forced expiratory volume in one second to forced vital capacity; $M R A$ mineralocorticoid receptor antagonist; $A C E I$ angiotensin converting enzyme inhibitor; $A R B$ angiotensin receptor blocker; $\beta B$ beta-blocker; $L V S D$ left ventricular systolic dysfunction; $L V E F$ left ventricular ejection fraction

levels, and were less likely to be prescribed a beta-blocker than patients with heart failure alone.

Patients with heart failure regardless of the presence of COPD were more likely to be male, have ischaemic heart disease and had a lower estimated glomerular filtration rate (eGFR) than patients without heart failure (Table 1).
Compared to patients with HeFREF, patients with $\mathrm{HeF}$ NEF were older, more likely to be female, less likely to have ischaemic heart disease (IHD), less likely to have severe symptoms, less likely to be prescribed loop diuretic and had lower NTproBNP levels (Table 2). 


\section{Associations with $\mathrm{FEV}_{1}: \mathrm{FVC}<0.7$}

On univariable analysis, there were weak positive correlations between $\mathrm{FEV}_{1}: \mathrm{FVC}$ ratio and body mass index (BMI), haemoglobin, eGFR and albumin; there were weak negative correlations between $\mathrm{FEV}_{1}: \mathrm{FVC}$ ratio and age and NTproBNP (Supplementary Fig. 2). Of these, only age $(\beta$ coefficient $=-0.14 ; t$-statistic $=-7.8)$ and BMI $(\beta=0.10 ; t=6.4)$ correlated with $\mathrm{FEV}_{1}: \mathrm{FVC}$ on multivariable analysis (data not shown).

\section{Outcome for all patients}

During a median follow-up of 1825 days (IQR 802-1825), 1551 patients died. Decreasing $\mathrm{FEV}_{1}: \mathrm{FVC}$ as a continuous variable and COPD as a categorical variable were associated with an increased risk of mortality in all patients, but not after adjustment for other variables such as age, NTproBNP, eGFR and NYHA class (Supplementary Table 1).

Patients with COPD alone were nearly twice as likely to die as patients with neither condition and patients with heart failure regardless of the presence of COPD were 4-5 times more likely to die than patients with neither condition (Fig. 1).

\section{Outcome for patients with heart failure}

Amongst all patients with heart failure, during a median follow-up of 1534 days (IQR 572-1825), 1347 patients died. Decreasing $\mathrm{FEV}_{1}: \mathrm{FVC}$ as a continuous variable and COPD as a categorical variable were associated with poor prognosis on univariable analysis. The presence of COPD was associated with poor prognosis on univariable analysis amongst patients with HeFREF but not amongst patients with HeFNEF (Fig. 2). Neither FEV 1 :FVC as a continuous variable nor COPD as a categorical variable were associated with outcome after adjustment for other variables (Supplementary Table 2).

\section{Discussion}

We have found that approximately half of patients with heart failure seen in a secondary care clinic have COPD (defined as $\mathrm{FEV}_{1}: \mathrm{FVC}<0.7$ ). Compared to patients with neither heart failure nor COPD, those with COPD alone were at a higher risk of death, but those with heart failure had a far greater risk of mortality regardless of the presence of COPD.

\section{The effect of a COPD diagnosis on heart failure}

The diagnosis of COPD in a patient with heart failure (regardless of phenotype) has a negligible impact on

Neither heart failure nor COPD

COPD

Heart failure

Heart failure \& COPD

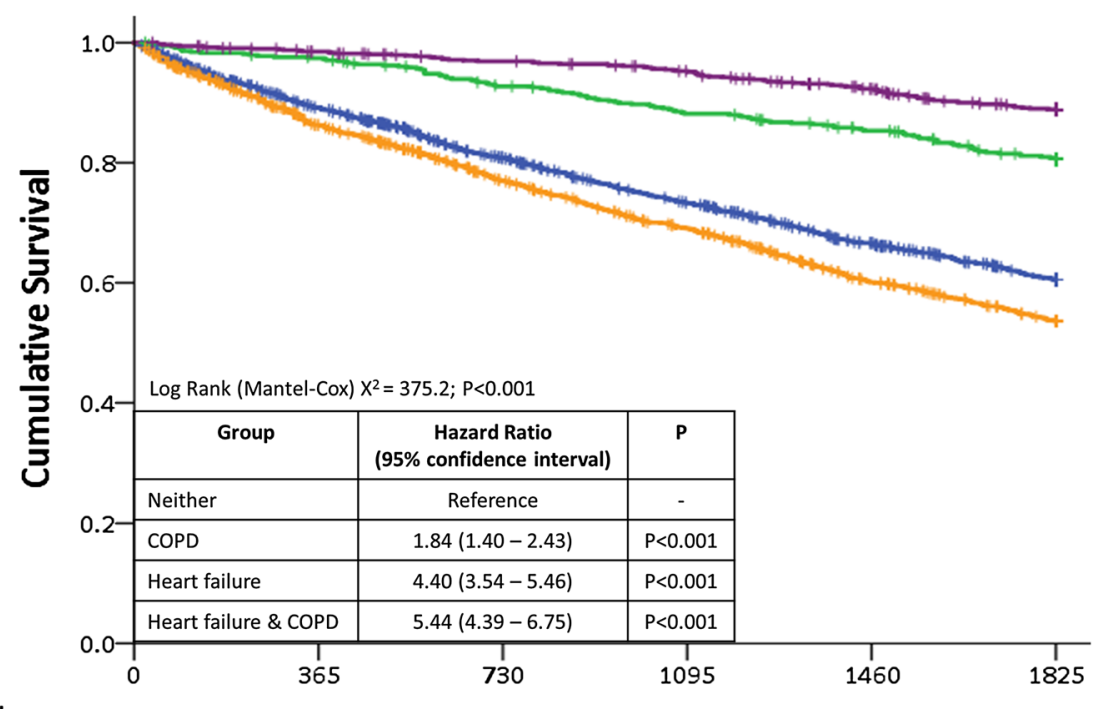

No. at risk

Neither

COPD

Heart failure

Heart failure \& COPD 1751

$\begin{array}{rr}886 & 861 \\ 585 & 565 \\ 1764 & 1483 \\ 1751 & 1427\end{array}$

835
530
1249
1209

Days

$\begin{array}{lll}813 & 766 & 717 \\ 502 & 476 & 441 \\ 1096 & 942 & 807 \\ 1059 & 877 & 757\end{array}$

Fig. 1 Survival curves for patients with heart failure, COPD, both or neither. Kaplan-Meier curves for 5-year mortality for patients with heart failure, COPD, both or neither. Abbreviations used: COPD chronic obstructive pulmonary disease. No number 


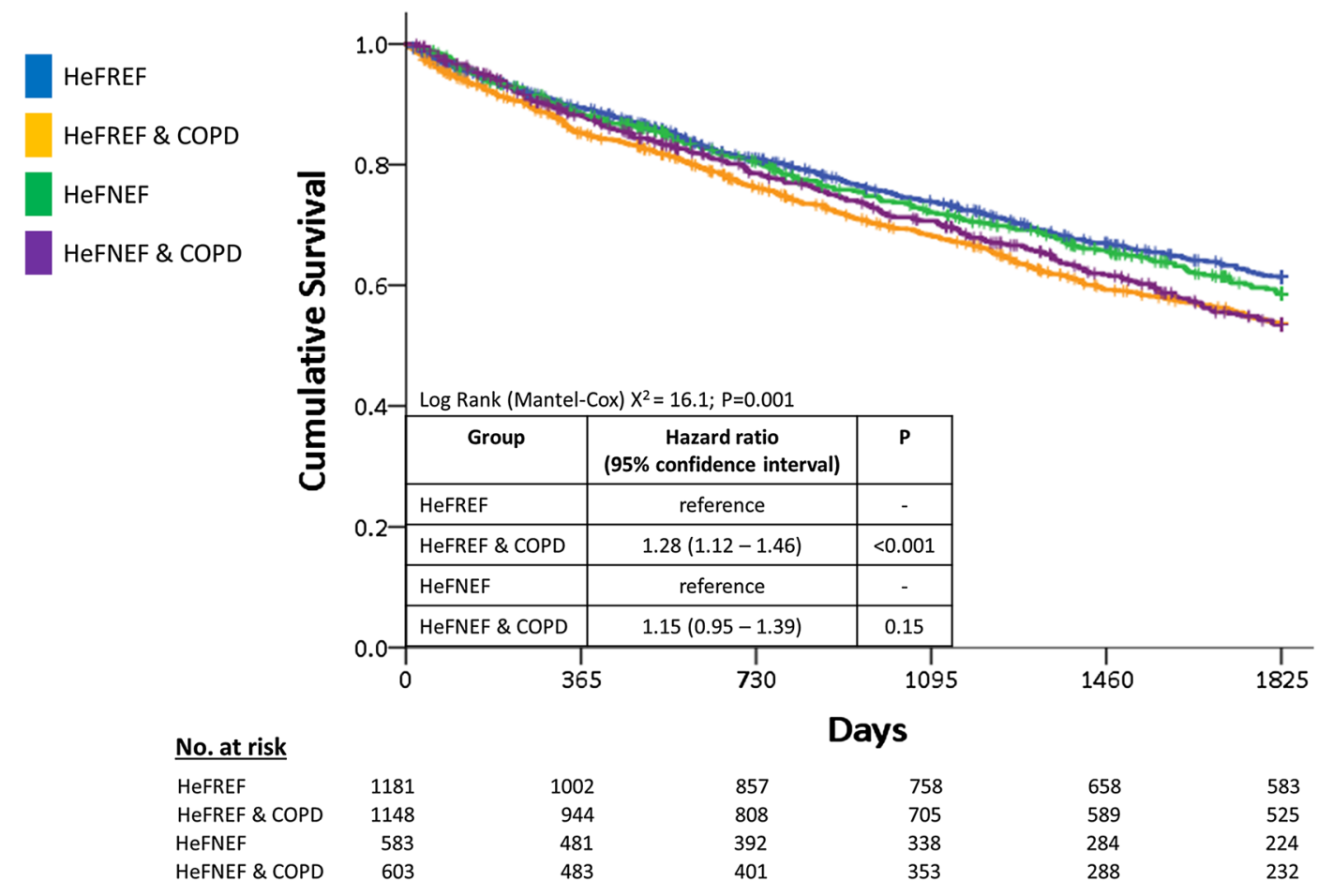

Fig. 2 Survival curves for patients with either HeFREF or HeFNEF with or without COPD. Kaplan-Meier curves for 5-year mortality for patients with heart failure with or without COPD. Abbreviations

outcome. This runs counter to the assertion in the current European Society of Cardiology heart failure guidelines that, regardless of definition, COPD is associated with worse outcome in patients with HeFREF [1].

Of all the studies that have demonstrated a significant association between the presence of COPD and increased risk of adverse outcome in patients with heart failure [6, $9-12,15,16,18-20,22]$ only three defined COPD using spirometry and heart failure using echocardiography or natriuretic peptide levels [6, 20, 22]; of these three studies, only one adjusted for natriuretic peptide levels and found an association between COPD and all-cause mortality or cardiovascular hospitalisation, but in a study of only 71 patients with HeFNEF [22]. Natriuretic peptide levels are powerful prognostic markers in patients with heart failure and may also be useful prognostic biomarkers in patients with COPD $[25,26]$. Our results suggest that in patients with heart failure, it is high natriuretic peptide levels (a marker of heart failure severity), not the presence of COPD, which increases the risk of adverse outcome.

However, the diagnosis of COPD in a patient with heart failure may have important implications for management. We found that the prevalence of COPD identified by abnormal spirometry is higher amongst patients with heart failure than recorded in the medical notes: COPD may be missed when breathlessness is attributed to the heart failure used: $C O P D$ chronic obstructive pulmonary disease; $H e F N E F$ heart failure with normal ejection fraction; HeFREF heart failure with reduced ejection fraction; No number

diagnosis. Registry data suggest that most patients with heart failure and COPD have the latter diagnosis confirmed without spirometry [27]. Indeed, most studies claiming to investigate the impact of COPD on outcome in patients with heart failure do not use spirometry to define COPD [9-11, 14-16, 19]. Under-diagnosis of COPD amongst patients with heart failure may be common.

Bronchodilators can improve symptoms of breathlessness in patients with COPD [28], but are unlikely to be prescribed in the absence of a diagnosis. There may be many patients with heart failure and undiagnosed COPD who are not receiving potentially symptom-relieving treatment.

An alternative explanation for the prevalence of COPD in our cohort is that heart failure may act as a mimic of COPD [5], possibly due to alveolar and pulmonary interstitial oedema compressing small airways [25, 29]. Medical treatment of heart failure can correct abnormal spirometry in approximately $50 \%$ of patients with heart failure and 'COPD' after 6 months [6], and optimising heart failure medications and diuretic dose according to invasively measured pulmonary artery pressure can reduce the risk of admission with respiratory illness [30]. As some of our cohort were new referrals and naïve to treatment, it is possible that a proportion of patients with "heart failure and COPD" merely had more severe heart failure rather than concurrent pulmonary disease. However, it is important to note, regardless 
of whether obstructive spirometry $\left(\mathrm{FEV}_{1}: \mathrm{FVC}<0.7\right)$ represents 'true COPD' or just more severe heart failure, it had no effect on mortality.

\section{The effect of a heart failure diagnosis on COPD}

We found that a co-diagnosis of COPD and heart failure is far worse than having COPD alone. Many patients with heart failure have obstructive spirometry but the opposite may also be true: symptoms of heart failure such as breathlessness and peripheral oedema may be misinterpreted as COPD [31, 32], particularly if the diagnosis of COPD is established: there may be cases of undiagnosed heart failure amongst patients with COPD [33]. This is a much more important situation than missing COPD in a patient with heart failure given the potent effects of medical therapy for patients with HeFREF [1].

Cardiovascular death is common amongst patients with COPD [34-39), and beta-blockers might reduce the risk of mortality amongst patients with COPD [39]. Whether other treatments that target cardiovascular risk (such as spironolactone) can improve outcome in patients with COPD (and not heart failure) is unknown. Screening patients with COPD for heart failure using natriuretic peptides could identify those at greater risk of adverse outcome, and should be considered if there is any doubt that a patient's symptoms are due to COPD alone.

\section{Study limitations}

The limitations of retrospective analyses apply to our study and confounding factors cannot be excluded. Our data represent a snapshot of a single time point and no conclusions can be drawn on the importance of changing spirometry or the effect of heart failure treatment on spirometry amongst patients with heart failure over time. Our data did not include reversibility studies as part of the spirometry, nor did we have data on hospitalisation rates.

Patients in whom COPD was the obvious cause of their symptoms are unlikely to have been referred to a heart failure service. The patients in our study with COPD alone are likely to be those with relatively mild disease and might thus not be truly representative of the 'real-world' COPD population. The role of our clinic is to identify and treat patients with heart failure, not identifying the specific underlying cause of breathlessness. For that reason we are unable to comment on the cause of breathlessness in the sub-group of patients with neither heart failure nor COPD $(N=886)$, although it is interesting to note that the average body mass index of patients in this group was higher than that of patients with heart failure and/or COPD (Table 1) and meets the National Institute of Clinical Excellence (NICE) diagnostic criteria for obesity [40].

\section{Conclusions}

The symptoms of heart failure and COPD overlap. Both carry an adverse prognosis. In patients with COPD, a coincident diagnosis of heart failure greatly worsens prognosis, but an additional diagnosis of COPD in patients with heart failure does not affect outcome.

Funding None.

\section{Compliance with ethical standards}

Conflict of interest No relationship to industry. No conflict of interest.

Open Access This article is distributed under the terms of the Creative Commons Attribution 4.0 International License (http://creativeco mmons.org/licenses/by/4.0/), which permits unrestricted use, distribution, and reproduction in any medium, provided you give appropriate credit to the original author(s) and the source, provide a link to the Creative Commons license, and indicate if changes were made.

\section{References}

1. Ponikowski P, Voors AA, Anker SD, Bueno H, Cleland JG, Coats AJ, Falk V, González-Juanatey JR, Harjola VP, Jankowska EA, Jessup M, Linde C, Nihoyannopoulos P, Parissis JT, Pieske B, Riley JP, Rosano GM, Ruilope LM, Ruschitzka F, Rutten FH, van der Meer P, Authors/Task Force Members; Document Reviewers (2016) 2016 ESC Guidelines for the diagnosis and treatment of acute and chronic heart failure: The Task Force for the diagnosis and treatment of acute and chronic heart failure of the European Society of Cardiology (ESC). Developed with the special contribution of the Heart Failure Association (HFA) of the ESC. Eur J Heart Fail 18(8):891-975

2. Calzetta L, Rogliani P, Matera MG, Cazzola M (2016) A systematic review with meta-analysis of dual bronchodilation with LAMA/LABA for the treatment of stable COPD. Chest 149(5):1181-1196

3. Lipworth B, Skinner D, Devereux G, Thomas V, Ling Zhi Jie J, Martin J, Carter V, Price DB (2016) Underuse of $\beta$-blockers in heart failure and chronic obstructive pulmonary disease. Heart 102(23):1909-1914

4. Vogelmeier CF, Criner GJ, Martinez FJ, Anzueto A, Barnes PJ, Bourbeau J, Celli BR, Chen R, Decramer M, Fabbri LM, Frith P, Halpin DM, López Varela MV, Nishimura M, Roche N, Rodriguez-Roisin R, Sin DD, Singh D, Stockley R, Vestbo J, Wedzicha JA, Agusti A (2017) Global strategy for the diagnosis, management, and prevention of chronic obstructive lung disease 2017 report: GOLD executive summary. Eur Respir J 49(3):1700214

5. Light RW, George RB (1983) Serial pulmonary function in patients with acute heart failure. Arch Intern Med 143(3):429-433

6. Brenner S, Güder G, Berliner D, Deubner N, Fröhlich K, Ertl G, Jany B, Angermann CE, Störk S (2013) Airway obstruction in systolic heart failure-COPD or congestion? Int J Cardiol 168(3):1910-1916

7. Griffo R, Spanevello A, Temporelli PL, Faggiano P, Carone M, Magni G, Ambrosino N, Tavazzi L, SUSPIRIUM Investigators (2017) Frequent coexistence of chronic heart failure and chronic obstructive pulmonary disease in respiratory and cardiac 
outpatients: evidence from SUSPIRIUM, a multicentre Italian survey. Eur J Prev Cardiol 24(6):567-576

8. Hawkins NM, Petrie MC, Jhund PS, Chalmers GW, Dunn FG, McMurray JJ (2009) Heart failure and chronic obstructive pulmonary disease: diagnostic pitfalls and epidemiology. Eur J Heart Fail 11(2):130-139

9. Staszewsky L, Wong M, Masson S, Barlera S, Carretta E, Maggioni AP, Anand IS, Cohn JN, Tognoni G, Latini R, Valsartan Heart Failure Trial Investigators (2007) Clinical, neurohormonal, and inflammatory markers and overall prognostic role of chronic obstructive pulmonary disease in patients with heart failure: data from the ValHeFT heart failure trial. J Card Fail 13(10):797-804

10. Macchia A, Monte S, Romero M, D’Ettorre A, Tognoni G (2007) The prognostic influence of chronic obstructive pulmonary disease in patients hospitalised for chronic heart failure. Eur J Heart Fail 9(9):942-948

11. Rusinaru D, Saaidi I, Godard S, Mahjoub H, Battle C, Tribouilloy C (2008) Impact of chronic obstructive pulmonary disease on longterm outcome of patients hospitalized for heart failure. Am J Cardiol 101(3):353-358

12. De Blois J, Simard S, Atar D, Agewall S, Norwegian Heart Failure Registry (2010) COPD predicts mortality in HF: the Norwegian Heart Failure Registry. J Card Fail 16(3):225-229

13. Mentz RJ, Schmidt PH, Kwasny MJ, Ambrosy AP, O'Connor CM, Konstam MA, Zannad F, Maggioni AP, Swedberg K, Gheorghiade M (2012) The impact of chronic obstructive pulmonary disease in patients hospitalized for worsening heart failure with reduced ejection fraction: an analysis of the EVEREST Trial. J Card Fail 18(7):515-523

14. Mentz RJ, Fiuzat M, Wojdyla DM, Chiswell K, Gheorghiade M, Fonarow GC, O'Connor CM (2012) Clinical characteristics and outcomes of hospitalized heart failure patients with systolic dysfunction and chronic obstructive pulmonary disease: findings from OPTIMIZE-HF. Eur J Heart Fail 14(4):395-403

15. Tavazzi L, Swedberg K, Komajda M, Böhm M, Borer JS, Lainscak M, Robertson M, Ford I, SHIFT Investigators (2013) Clinical profiles and outcomes in patients with chronic heart failure and chronic obstructive pulmonary disease: an efficacy and safety analysis of SHIFT study. Int J Cardiol 170(2): 182-188

16. Fisher KA, Stefan MS, Darling C, Lessard D, Goldberg RJ (2015) Impact of COPD on the mortality and treatment of patients hospitalized with acute decompensated heart failure: the Worcester Heart Failure Study. Chest 147(3):637-645

17. Jacob J, Tost J, Miró Ò, Herrero P, Martín-Sánchez FJ, Llorens P, ICA-SEMES Research Group (2017) Impact of chronic obstructive pulmonary disease on clinical course after an episode of acute heart failure. EAHFE-COPD study. Int J Cardiol 227:450-456

18. Testa G, Cacciatore F, Bianco A, Della-Morte D, Mazzella F, Galizia G, Gargiulo G, Curcio F, Liguori I, Sabusco A, Rengo F, Bonaduce D, Abete P (2017) Chronic obstructive pulmonary disease and longterm mortality in elderly subjects with chronic heart failure. Aging Clin Exp Res 29(6):1157-1164

19. Canepa M, Temporelli PL, Rossi A, Rossi A, Gonzini L, Nicolosi GL, Staszewsky L, Marchioli R, Maggioni AP, Tavazzi L, GISSI-HF Investigators (2017) Prevalence and prognostic impact of chronic obstructive pulmonary disease in patients with chronic heart failure: data from the GISSI-HF trial. Cardiology 136(2):128-137

20. Canepa M, Straburzynska-Migaj E, Drozdz J, Fernandez-Vivancos C, Pinilla JMG, Nyolczas N, Temporelli PL, Mebazaa A, Lainscak M, Laroche C, Maggioni AP, Piepoli MF, Coats AJS, Ferrari R, Tavazzi L, ESC-HFA Heart Failure Long-Term Registry Investigators (2018) Characteristics, treatments and 1-year prognosis of hospitalized and ambulatory heart failure patients with chronic obstructive pulmonary disease in the European Society of Cardiology Heart Failure Long-Term Registry. Eur J Heart Fail 20(1):100-110
21. Andrea R, López-Giraldo A, Falces C, Sobradillo P, Sanchis L, Gistau C, Heras M, Sabate M, Brugada J, Agustí A (2014) Lung function abnormalities are highly frequent in patients with heart failure and preserved ejection fraction. Heart Lung Circ 23(3):273-279

22. Andrea R, López-Giraldo A, Falces C, López T, Sanchis L, Gistau C, Sabaté M, Sitges M, Brugada J, Agustí À (2018) Pulmonary function predicts mortality and hospitalizations in outpatients with heart failure and preserved ejection fraction. Respir Med 134:124-129

23. Lüscher T (2018) Heart failure subgroups: HFrEF, HFmrEF, and HFpEF with or without mitral regurgitation. Eur Heart J 39:1-4

24. National Institute for Health and Care Excellence (2010) Chronic heart failure in adults: management (clinical guideline CG108). https ://www.nice.org.uk/guidance/cg108/chapter/1-Guidance\#diagnosing -heart-failure. Accessed on 21 Mar 2018

25. Pavasini R, Tavazzi G, Biscaglia S, Guerra F, Pecoraro A, Zaraket F, Gallo F, Spitaleri G, Contoli M, Ferrari R, Campo G (2017) Amino terminal pro brain natriuretic peptide predicts all-cause mortality in patients with chronic obstructive pulmonary disease: Systematic review and meta-analysis. Chron Respir Dis 14(2):117-126

26. Stolz D, Meyer A, Rakic J, Boeck L, Scherr A, Tamm M (2014) Mortality risk prediction in COPD by a prognostic biomarker panel. Eur Respir J 44(6):1557-1570

27. Magnussen H, Canepa M, Zambito PE, Brusasco V, Meinertz T, Rosenkranz S (2017) What can we learn from pulmonary function testing in heart failure? Eur J Heart Fail 19(10):1222-1229

28. Cazzola M, Page CP, Calzetta L, Matera MG (2012) Pharmacology and therapeutics of bronchodilators. Pharmacol Rev 64(3):450-504

29. Güder G, Brenner S, Störk S, Hoes A, Rutten FH (2014) Chronic obstructive pulmonary disease in heart failure: accurate diagnosis and treatment. Eur J Heart Fail 16(12):1273-1282

30. Krahnke JS, Abraham WT, Adamson PB, Bourge RC, Bauman J, Ginn G, Martinez FJ, Criner GJ, Champion Trial Study Group (2015) Heart failure and respiratory hospitalizations are reduced in patients with heart failure and chronic obstructive pulmonary disease with the use of an implantable pulmonary artery pressure monitoring device. J Card Fail 21(3):240-249

31. de Leeuw PW, Dees A (2003) Fluid homeostasis in chronic obstructive lung disease. Eur Respir J Suppl 46:33s-40s

32. Remes J, Miettinen H, Reunanen A, Pyörälä K (1991) Validity of clinical diagnosis of heart failure in primary health care. Eur Heart J 12(3):315-321

33. Rutten FH, Cramer MJ, Grobbee DE, Sachs AP, Kirkels JH, Lammers JW, Hoes AW (2005) Unrecognized heart failure in elderly patients with stable chronic obstructive pulmonary disease. Eur Heart J 26:1887-1894

34. Lahousse L, Niemeijer MN, van den Berg ME, Rijnbeek PR, Joos GF, Hofman A, Franco OH, Deckers JW, Eijgelsheim M, Stricker BH, Brusselle GG (2015) Chronic obstructive pulmonary disease and sudden cardiac death: the Rotterdam study. Eur Heart J 36:1754-1761

35. Müllerova H, Agusti A, Erqou S, Mapel DW (2013) Cardiovascular comorbidity in COPD: systematic literature review. Chest 144:1163-1178

36. Curkendall SM, DeLuise C, Jones JK, Lanes S, Stang MR, Goehring E Jr, She D (2006) Cardiovascular disease in patients with chronic obstructive pulmonary disease, Saskatchewan Canada cardiovascular disease in COPD patients. Ann Epidemiol 16:63-70

37. Jensen HH, Godtfredsen NS, Lange P, Vestbo J (2006) Potential misclassification of causes of death from COPD. Eur Respir J 28:781-785

38. Sin DD, Man SF (2003) Why are patients with chronic obstructive pulmonary disease at increased risk of cardiovascular diseases? The potential role of systemic inflammation in chronic obstructive pulmonary disease. Circulation 107:1514-1519 
39. Short PM, Lipworth SI, Elder DH, Schembri S, Lipworth BJ (2011) Effect of beta blockers in treatment of chronic obstructive pulmonary disease: a retrospective cohort study. BMJ 342:d2549

40. National Institute for Health and Clinical Excellence CG189 (2014) Obesity: identification, classification and management.
NICE, London. https://www.nice.org.uk/guidance/cg189. Accessed on 9th July 2017 